\title{
Integrasi Wilayah Secara Ekonomi Dan Spacial Serta Dampaknya Terhadap Pembangunan Daerah Di Lombok Barat NTB
}

\author{
Hailuddin*; Diswandi; and Irwan Suriadi \\ Faculty of Business \& Economic, Universitas Mataram, Lombok - 83125 \\ *Corresponding Author: didinunram@gmail.com
}

\section{Info Artikel}

Kata Kunci:

Pusat pertumbuhan, daerah pendukung, interaksi ekonomi, spread effect .

Penelitian dengan judul "Analisis Integrasi Wilayah Secara Ekonomi Dan Spacial Di Lombok Barat NTB” bertujuan untuk mengetahui interaksi dan integrasi secara ekonomi dan spasial Kecamatan Gerung dan wilayah pendukungnya dalam pembangunan wilayah di Lombok Barat. Metode yang digunakan adalah metode deskriptif kuantitatif dengan menggunakan data sekunder time series. Analisis data dilakukan dengan mengkaji tingkat pertumbuhan ekonomi, Model Gravitasi dan Indeks Williamson. Hasil penelitian menunjukkan bahwa secara simultan pusat pertumbuhan wilayah (Gerung) dan daerah pendukungnya mengalami kenaikan pertumbuhan ekonomi secara nyata selama pengamatan. Selain itu Kecamatan Gerung memiliki daya tarik yang kuat terhadap daerah belakangnya terutama bagi daerah yang berdekatan (Kecamatan Kuripan dan Labuapi). Demikian juga jika dilihat dari kemerataan pertumbuhan ekonominya, antara Gerung dan daerah pendukungnya secara simultan relatif merata. Kecamatan Labuapi merupakan kecamatan yang paling seimbang (tidak timpang) dengan Gerung, karena memiliki nilai Indeks Williamson paling rendah. Dengan demikian Kecamatan Gerung sebagai pusat pertumbuhan telah mampu memberikan spread effect terhadap wilayah/kecamatan pendukungnya. Untuk itu eksistensi kondisi tersebut harus tetap dijaga, dengan saling mendukung antar wilayah setempat dalam kegiatan pembangunan disegala bidang.
\end{abstract}

\section{ABSTRACT}

\section{PENDAHULUAN}

Pembangunan wilayah pada dasarnya adalah upaya yang dilakukan pemerintah daerah dan masyarakat dalam mengelola sumberdaya yang ada agar mampu menciptakan lapangan kerja dan merangsang pertumbuhan ekonomi dalam wilayah tersebut, dan tujuan akhirnya adalah terciptanya kesejahteraan masyarakat. Pembangunan daerah dan pengembangan tata ruang merupakan bagian yang terkait satu sama lain dalam rangka pengembangan wilayah. Demikian juga pengembangan tata ruang akan terkait pula dengan pengembangan sektoral.
Perencanaan tatat ruang wilayah pada dasarnya adalah menetapkan bagian-bagian wilayah (zona) yang diatur penggunaannya dan ada bagian wilayah yang tidak diatur penggunannya (Duran, H. E.; 2019).

Secara makro, dalam perencanaan wilayah ada kegiatan perkotaan dan ada kegiatan non perkotaan dengan fokus utama menciptakan hubungan yang serasi antara kota dengan wilayah belakangnya. Pada perencanaan wilayah kota, kegiatan utama adalah kegiatan perkotaan dan pemukiman sehingga yang menjadi fokus perhatian adalah keserasian hubungan antara berbagai kegiatan 


\section{Elastisitas - Jurnal Ekonomi Pembangunan \\ Vol. 2 No. 1, Maret 2020}

didalam kota untuk melayani kebutuhan masyarakat perkotaan itu sendiri plus kebutuhan masyarakat yang datang dari luar kota (Hailuddin dkk.,2016).

Jika dikaji secara spesifik, perencanaan wilayah perkotaan dan pedesaan tentu saja berbeda. Karenanya dalam perencanaan wilayah perlu menetapkan suatu tempat permukiman atau tempat berbagai kegiatan berlangsung di suatu daerah sehingga dapat dikategorikan sebagai kota atau bukan. Kota memiliki fungsi yang berbeda sehingga kebutuhan fasilitasnya pun berbeda dibanding daerah pedesaan atau pedalaman. Di pedesaan terdapat lokasi permukiman ditambah dengan berbagai kegiatan nonpertanian, seperti perdagangan, warung kopi, tukang pangkas, dan tukang jahit pakaian. Walaupun dalam jumlah dan intensitas yang kecil dan biasanya hanya ditujukan untuk melayani kebutuhan masyarakat setempat. Karena fungsinya yang berbeda, kebijakan pembangunan pun bisa berbeda antara wilayah perkotaan dengan wilayah pedesaan (Tarigan, 2005).

Pembangunan perkotaan biasanya diikuti oleh pembangunan infrastruktur, transportasi, komunikasi dan kelembagaan sosial yang secara alami dapat meningkatkan daya tarik investasi (Jin, C., Xu, J., \& Huang, Z.; 2019). Implikasinya terhadap kegiatan ekonomi yang terjadi di masyarakat adalah bagaimana hasil produksi dari pusat-pusat pertumbuhan tersebut (perkotaan), dapat dipakai untuk melaksanakan kegiatan ekonomi bagi daerah sekitar pusat pertumbuhan (hinterland). Sebaliknya bagaimana produksi hasil daerah hinterland tersebut bisa bermanfaat untuk kegiatan ekonomi yang ada di pusat pertumbuhan. Kondisi ini akan menciptakan hubungan timbal balik yang akan menjadi akselerator bagi pertumbuhan perekonomian daerah.

Daerah perkotaan sebagai pusat pertumbuhan, secara geografis merupakan suatu lokasi yang banyak memiliki fasilitas dan kemudahan yang menyebabkan berbagai macam usaha tertarik untuk berlokasi di daerah tersebut dan masyarakat senang untuk datang memanfaatkannya. Makin besar suatu kota, maka makin luas wilayah pengaruhnya. Suatu kota yang besar selain memiliki daerah belakang yang berupa daerah pertanian juga beberapa kota kecil (kecamatan). Bila kotakota kecil banyak tergantung pada kota besar maka kota kecil termasuk dalam daerah pengaruh dari kota yang lebih besar. Interaksi tersebut bisa dalam bentuk jual-beli berbagai keperluan dan juga pergerakan penduduk yang bekerja, mencari tempat pendidikan, dan berbagai urusan lain ke kota besar (Chapple, K., \& Montero, S.; 2016).

Lombok Barat sebagai salah satu Kabupaten di Provinsi Nusa Tenggara Barat memiliki beberapa kecamatan yang saling mendukung dalam pembangunan daerah. Kegiatan perekonomian serta pemerintahan berpusat di Kecamatan Gerung, yang sekaligus merupakan ibukota Kabupaten Lombok Barat. Beberapa kecamatan pendukung yang melingkupi Gerung antaranya adalah Kecamatan Kediri, Labuapi, Lembar, dan Kuripan. Penetapan Gerung sebagai pusat pertumbuhan dilakukan sebagai salah satu strategi dasar didalam pembangunan daerah sesuai dengan kondisi wilayah. Sebagai ibukota kabupaten, Gerung tentu memiliki tingkat perekonomian yang lebih baik, sehingga dapat memberikan spread effects untuk daerah sekitarnya (hinterland) secara ekonomi (Adisasmita, 2005). Salah satu tolok ukurnya adalah pertumbuhan nilai PDRB.

Dengan gambaran tersebut, sejauhmana interaksi antara Gerung sebagai pusat pertumbuhan Lombok Barat dengan kota kecil pendukungnya (kecamatan sekitar). Inilah yang menjadi daya tarik untuk mengkaji lebih mendalam tentang integrasi wilayah secara ekonomi dan spasial di Lombok Barat khususnya. Apakah Gerung sebagai pusat pertumbuhan, mampu memberikan kontribusi yang bersifat spread effects terhadap wilayah/kecamatan di sekitarnya. Hal ini tentu akan sangat bermakna untuk pengembangan kawasan-kawasan lain disekitarnya. 


\section{Elastisitas - Jurnal Ekonomi Pembangunan \\ Vol. 2 No. 1, Maret 2020}

\section{KAJIAN PUSTAKA}

\section{A. Konsepsi Teori Lokasi}

Secara konseptual, teori lokasi merupakan teori dasar yang memiliki peran penting dalam analisa spasial, dimana tata ruang dan lokasi kegiatan ekonomi merupakan unsur utama. Hal ini berkaitan dengan teori lokasi yang mampu memberikan kerangka analisa yang baik dan sistematis mengenai pemilihan lokasi kegiatan ekonomi dan sosial, serta analisa interaksi antar wilayah. Teori ini menjadi penting dalam analisa ekonomi karena pemilihan lokasi yang baik akan dapat memberikan penghematan yang sangat besar untuk ongkos angkut sehingga mendorong terjadinya efisiensi baik dalam bidang produksi maupun pemasaran. Disisi lain interaksi antar wilayah akan dapat pula mempengaruhi perkembangan bisnis yang pada gilirannya akan dapat pula mendorong pertumbuhan ekonomi wilayah bersangkutan, (Sjafrizal, 2012).

Pembangunan suatu wilayah akan memberi kontribusi yang signifikan jika setiap kegiatan pembangunan sepenuhnya sudah memperhitungkan lokasi yang tepat sesuai peruntukannya (Blair, N., Berry, J., \& McGreal, S.; 2007). Peruntukan lokasi yang tepat tersebut, akan memberikan dan meningkatkan efisensi dan efektifitas sumber daya pembangunan yang ada. Penetapan suatu suatu pusat kegiatan pada dasarnya sudah memperhitungkan banyak aspek, baik ekonomi, sosial, budaya dan faktor lingkungan lainnya. Oleh karena itu jika semua aspek tersebut sudah diperhitungkan dengan benar, maka tentu hal ini akan menjadi faktor yang cukup berkontribusi pada pengembangan wilayah.

\section{B. Pusat pertumbuhan (growth poles)}

Pembangunan pada suatu wilayah seringkali mengacu pada kondisi sosial ekonomi wilayah bersangkutan. Richardson sendiri membuat klasifikasi berdasarkan tingkat kemakmuran dan kemampuan berkembang masing-masing wilayah. Tingkat kemakmuran dinyatakan dengan pendapatan regional per-kapita, dan kemampuan berkembang dicerminkan oleh laju pertumbuhan pembangunan, (Adisasmita, 2008).

Berdasarkan pemilikan potensi yang berbeda, akan menimbulkan disparitas pembangunan antar wilayah, bisa terjadi pada suatu kota dengan daerah sekitarnya. Kota dengan kepadatan penduduk tinggi, yang sebagian lahannya terbangun, dan perekonomiannya bersifat non pertanian. Selain itu, kota merupakan pusat kegiatan ekonomi yang menghubungkan kegiatan pertanian wilayah sekitarnya dan tempat pemrosesan serta pemasaran bahan baku bagi industri (Hailuddin dkk, 2018).

Dari gambaran tersebut, kebanyakan kota akan menjadi pusat pertumbuhan (growth poles). Hal ini terjadi karena kota mempunyai keuntungan-keuntungan lokasi. Karakteristik utama yang dimiliki sebuah pusat pertumbuhan antaranya: (a) Adanya sekelompok kegiatan ekonomi terkonsentrasi pada suatu lokasi tertentu; (b) Konsentrasi kegiatan ekonomi tersebut mampu mendorong pertumbuhan ekonomi yang dinamis dalam perekonomian; (c) Terdapat keterkaitan input dan output yang kuat antara sesama kegiatan ekonomi pada pusat tersebut, dan (d) Dalam kelompok kegiatan ekonomi tersebut terdapat sebuah industri induk yang mendorong pengembangan kegiatan ekonomi pada pusat tersebut (Sjafrizal, 2012).

Oleh karena itu pusat pertumbuhan memiliki peran penting sebagai sarana dan strategi pembangunan wilayah, dimana pembangunan industri merupakan jalan utama untuk menciptakan kutub pertumbuhan dan pembangunan ekonomi. Perkembangan pusat pertumbuhan beserta daerah kotanya akan memiliki pengaruh timbal balik terhadap wilayah belakangnya (hinterland) (Athukorala, P, \& Narayanan, S.; 2018). Pengaruh ini dapat menguntungkan maupun merugikan. Menguntungkan jika kemajuan kota sebagai pusat pertumbuhan merembet keluar, baik dalam bentuk perdagangan, atau penanaman modal dari wilayah kota di wilayah sekitarnya. Pengaruh semacam ini akan terjadi 


\section{Elastisitas - Jurnal Ekonomi Pembangunan \\ Vol. 2 No. 1, Maret 2020}

jika perekonomian kedua daerah bersifat komplementer (Nining, 2009).

\section{Daerah Pendukung (Hinterland)}

Daerah pendukung/belakang pada dasarnya adalah daerah yang mampu berinteraksi secara langsung dengan pusat pertumbuhan (kota) (Ali, M. J., \& Varshney, D.; 2013). Daerah ini memiliki kontribusi untuk mendukung aktivitas dan pertumbuhan daerah diatasnya. Hinterland bisa berupa suatu pelabuhan, dimana luasnya relatif dan tidak mengenal batas administratif suatu daerah. Disamping itu jaringan lalu lintas perhubungan darat; jalan raya, kereta api, dan lalu lintas sungai memegang peranan penting pula untuk daerah belakang tersebut. Oxford University (dalam Gulo, 2015), memberikan pengertian tentang hinterland adalah sebagai berikut;

a. The land directly adjacent to and inland from a coast.

b. A region serves by aport city and its facilities.

c. A region remote from urban areas: back country.

Mengingat pertumbuhan sosial dan ekonomi sangat dipengaruhi oleh gerak laju pertumbuhan sektor ekonomi terutama sektor yang memiliki peranan dominan, maka hal ini akan berpengaruh terhadap perkembangan jumlah penduduk disertai dengan mobilitasnya yang terus meningkat. Perkembangan ini akan menyebabkan terjadinya perubahan terhadap hirarki dan fungsi yang terkait dengan masalah ketenagakerjaan (Nischalke, T., \& Schöllmann, A.; 2005). Dan semua ini akan memberikan implikasi terhadap kebutuhan prasarana dan sarana perkotaan untuk mendukungnya.

\section{METODE}

Penelitian ini merupakan penelitian deskriptif kuantitatif, yang menekankan pada pencarian fakta dengan interpretasi yang tepat. Lokasi penelitiannya Kabupaten Lombok Barat dengan keadaan geografis dan demografisnya yang cukup mendukung. Daerah ini memiliki sumber daya alam dan air yang cukup melimpah, serta lokasi wisata yang potensial menjadikan Kabupaten ini memiliki masa depan yang baik untuk berkembang dimasa datang.

Teknik pengumpulan datanya dengan observasi tidak langsung, yaitu dengan membaca, mengumpulkan, mencatat datadata, informasi dan keterangannya. Jenis data yang digunakan dalam penelitian ini adalah data kuantitatif dalam bentuk data sekunder time series. Data dimaksud antaranya data PDRB, geografis, jumlah penduduk, jarak antara wilayah, potensi daerah dan data lainnya, yang bersumber dari Badan pusat Statistik (BPS) Provinsi NTB, BPS dan BAPPEDA Kabupaten Lombok Barat, serta sumber on-line.

Selanjutnya variable yang terkait dengan penelitian ini antaranya adalah:

1) Jarak Antar Wilayah

Jarak adalah panjang garis dari suatu titik ke titik lainnya. Sehingga dalam penelitian ini jarak yang dimaksud adalah jarak antara Kecamatan Gerung dengan kecamatan lain di sekitarnya yang menjadi kajian. Satuan yang dipakai adalah kilometer.

2) Penduduk

Penduduk adalah seluruh orang yang berdomisili di wilayah geografis selama 6 bulan atau lebih dan atau mereka yang berdomisili kurang dari 6 bulan tetapi bertujuan untuk menetap. Dalam penelitian ini jumlah penduduk Kecamatan Gerung yang didata dengan acuan tersebut, demikian juga untuk kecamatan lainnya. Satuan variabel penduduk yaitu orang/jiwa.

3) Produk Domestik Regional Bruto (PDRB)

Produk Domestik Regional Bruto (PDRB) adalah jumlah nilai tambah yang timbul dari semua unit produksi di dalam suatu wilayah dalam jangka waktu tertentu. PDRB yang digunakan dalam penelitian ini adalah PDRB Kecamatan Gerung dan kecamatan lain di sekitarnya atas dasar harga konstan tahun 2000 dalam satuan rupiah.

4). Pendapatan Per Kapita

Pendapatan Per Kapita adalah pendapatan rata-rata penduduk suatu daerah pada periode tertentu. Pendapatan per kapita 


\section{Elastisitas - Jurnal Ekonomi Pembangunan \\ Vol. 2 No. 1, Maret 2020}

dihitung dengan cara membagi jumlah PDRB suatu daerah dengan jumlah penduduk daerah tersebut. Satuan variabel pendapatan per kapita adalah rupiah.

Analisis Data dilakukan dengan pendekatan alat analisis sebagai berikut;

\section{A. Mengukur Pertumbuhan Ekonomi}

Untuk mengukur tingkat pertumbuhan ekonomi wilayah pusat pertumbuhan dan wilayah pendukungnya (hinterland), digunakan nilai pertumbuhan PDRB selama 5 tahun atas dasar harga konstan 2010 untuk kedua katagori wilayah tersebut, dengan rumus;

$$
\triangle \mathrm{PDRB}=\frac{\text { PDRBt }- \text { PDRBt }-1}{\text { PDRBt }-1}
$$

Dimana:

$$
\begin{aligned}
\triangle \mathrm{PDRB}= & \text { Pertumbuhan Produk Domestik } \\
& \text { Regional Bruto. } \\
\text { PDRBt }= & \text { Produk Domestik Regional Bruto } \\
& \text { tahun tertentu. } \\
\text { PDRBt-1 }= & \text { Produk Domestik Regional Bruto } \\
& \text { tahun sebelumnya. }
\end{aligned}
$$

\section{B. Analisa Model Gravitasi}

Model ini digunakan untuk analisis perencanaan kota yang menganggap bahwa faktor aglomerasi penduduk, pemusatan kegiatan atau potensi sumber daya alam yang dimiliki, mempunyai daya tarik yang dapat dianalogikan sebagai daya tarik menarik antara 2(dua) kutub magnet. Persamaan model Gravitasi (Hendarto, 2014) ini adalah:

$$
\mathrm{Tij}=\frac{P i x P j}{D i j^{2}}
$$

Dimana:

Tij $=$ pergerakan penduduk tempat $\mathrm{i}$ ke tempat $\mathrm{j}$

$\mathrm{Pi}=$ jumlah penduduk di tempat $\mathrm{i}$

$\mathrm{Pj}=$ jumlah penduduk di tempat $\mathrm{j}$

Dij $=$ jarak antara tempat $\mathrm{i}-$ tempat $\mathrm{j}$

\section{Indeks Williamson}

Indek ini dipakai untuk mengukur perbandingkan tingkat pembangunan antar wilayah. Dengan demikian apakah suatu daerah pusat pertumbuhan memberikan peranan terhadap daerah sekitarnya. Formulasi Indeks Williamson ini secara 57tatistic sebagai berikut (Arsyad, 2000):

$$
V w=\frac{\sqrt{(y i-y)^{2}(f i / n)}}{y}, \quad \text { acuannya; } 0<\mathrm{V}_{\mathrm{w}}<1
$$

Dimana:

yi $=$ PDRB per kapita daerah $\mathrm{i}$

$\mathrm{y}=$ PDRB per kapita rata-rata seluruh daerah

$\mathrm{f}_{\mathrm{i}}=$ Jumlah penduduk daerah $\mathrm{i}$

$\mathrm{n}=$ Jumlah penduduk seluruh daerah

Subskrip w digunakan karena formulasi yang dipakai adalah secara tertimbang (weighted) agar indeks tersebut menjadi lebih stabil dan dapat dibandingkan dengan negara atau daerah lainnya. Sedangkan kriteria indeks ini adalah; bila $V_{w}$ mendekati 1 berarti daerah itu sangat timpang dan bila $V_{w}$ mendekati nol berarti sangat merata.

\section{HASIL PENELITIAN}

Kabupaten Lombok Barat dengan luas wilayah 1.053,92 km², dan jumlah penduduk 675.222 jiwa, dengan kepadatan rata-rata 650 jiwa $/ \mathrm{km}^{2}$. Secara administratif terdiri dari 10 Kecamatan (Sekotong, Lembar, Gerung, Kediri, Labuapi, Kuripan, Narmada, Lingsar, Gunungsari, dan Batulayar), 122 desa/kelurahan dan 844 dusun.

Dari aspek perekonomian, sektor pertanian masih dominan perannya terhadap perekonomian daerah, dengan kontribusi sebesar 20,38 persen. Disusul berikutnya oleh sektor perdagangan 13,18 persen, konstruksi 12,75 persen, jasa-jasa 12,31 persen dan sektor transportasi 9,9 persen (BPS Lombok Barat, 2018). Sedangkan sektor-sektor lainnya belum terlalu menonjol perannya. Namun secara umum terlihat bahwa meski saat ini sektor pertanian masih dominan perannya, namun secara terstruktur pola perekonomian Lombok Barat mulai bergeser dari sektor primer 


\section{Elastisitas - Jurnal Ekonomi Pembangunan \\ Vol. 2 No. 1, Maret 2020}

kesektor sekunder dan tersier, yang tentunya hal ini merupakan sesuatu yang baik bagi perekonomian karena akan mampu memberikan nilai tambah yang makin baik pua kedepan.

\section{A. Pertumbuhan Ekonomi Daerah Pusat Pertumbuhan dan Daerah Pendukung}

Untuk mengukur kemajuan ekonomi wilayah pusat pertumbuhan dan wilayah pendukungnya (hinterland), digunakan nilai pertumbuhan PDRB selama 3 tahun atas dasar harga konstan 2010 pada kedua katagori wilayah tersebut. Laju pertumbuhan ekonomi yang terus meningkat dan konsisten, dapat mencerminkan pengaruh yang positif dari pusat pertumbuhan terhadap daerah pendukungnya.

Tabel 1. Perkembangan PDRB dan Laju Pertumbuhan Wilayah Pusat Pertumbuhan dan Daerah Pendukung.

\begin{tabular}{|l|r|c|r|r|r|c|}
\hline \multirow{2}{*}{ Kecamatan } & \multicolumn{2}{|c|}{$\mathbf{2 0 1 5}$} & \multicolumn{2}{c|}{$\mathbf{2 0 1 6}$} & \multicolumn{2}{c|}{ 2017 } \\
\cline { 2 - 7 } & \multicolumn{1}{|c|}{ PDRB } & Laju $\Delta$ & PDRB & Laju $\Delta$ & PDRB & Laju $\Delta$ \\
\hline Lembar & $1.098 .752,47$ & 5,07 & $1.161 .357,37$ & 4,86 & 1.237 .264 & 5,68 \\
\hline Gerung & $1.229 .379,87$ & 5,13 & $1.299 .427,68$ & 5,15 & 1.384 .359 & 5,55 \\
\hline Labuapi & $895.863,10$ & 5,25 & $946.907,73$ & 5,45 & 1.008 .798 & 5,64 \\
\hline Kediri & $692.973,73$ & 5,09 & $732.458,10$ & 4,99 & 780.332 & 5,20 \\
\hline Kuripan & $386.323,59$ & 4,92 & $408.335,60$ & 4,92 & 435.025 & 4,98 \\
\hline
\end{tabular}

Sumber: Data diolah.

Dengan mengacu pada tabel diatas dapat dijelaskan bahwa perkembangan PDRB pusat pertumbuhan dan 4 daerah pendukungnya menunjukkan kecenderungan yang terus meningkat tiap tahun. Demikian juga dengan tingkat pertumbuhannya, cenderung menunjukkan trend yang terus meningkat. Meskipun Lembar dan Kediri sedikit fluktuatif, namun secara rata-rata mengarah pada peningkatan. Sedangkan 3 kecamatan lain (Gerung, Kediri dan Kuripan), pertumbuhannya menaik secara konsisten. Keadaan ini tentu sangat menggembirakan, mengingat pusat pertumbuhan (Gerung) dan daerah pendukung dapat tumbuh secara simultan. Jika dikaji lebih mendalam perkembangan ini, wilayah-wilayah tersebut memang memiliki irisan satu dengan lainnya, sehingga setiap gerak pembangunan disuatu daerah akan berimbas pada daerah sekitanya. Demikian sebaiknya. Gerung sebagai pusat pertumbuhan, tentu memiliki peran lebih besar sebagai penggerak pembangunan di Lombok Barat, mengingat posisinya sebagai ibukota kabupaten. Dan karenanya setiap aktivitas pembangunan pada berbagai bidang tentunya akan berimbas pada daerah sekitarnya (pendukung). Efek selanjutnya akan terciptanya pertumbuhan secara terintegrasi/ bersama dari daerah/wilayah tersebut.

\section{B. Daya Tarik Pusat Pertumbuhan (Gerung) Pada Daerah Sekitar (Pendukung).}

Dukungan dan daya tarik suatu wilayah pada wilayah lainnya dapat dilihat dari hubungan antara daerah tersebut yang diumpamakan dengan hubungan antar kutub magnit wilayah yang mempunyai daya tarik yang menyebabkan terjadinya interaksi. Semakin besar fungsi suatu daerah maka sarana yang dimiliki akan lebih besar dibandingkan dengan daerah lainnya. Tempat-tempat yang sarananya lebih lengkap akan memiliki daya tarik yang lebih kuat dibandingkan daerah yang lain. Kecamatan Gerung sebagai pusat pemerintahan kabupaten tentu memiliki banyak kelebihan dibandingkan kecamatan lain di Lombok Barat. Karena itu hubungan antara Kecamatan Gerung dengan daerah 


\section{Elastisitas - Jurnal Ekonomi Pembangunan \\ Vol. 2 No. 1, Maret 2020}

sekitanya (pendukung), dengan analisis pendekatan Model Gravitasi, dapat dilihat hasilnya seperti dalam tabel berikut:

Tabel 2. Hasil Perhitungan Model Gravitasi Kecamatan Gerung Dengan

Kecamatan Sekitar (Pendukung) Tahun 2018

\begin{tabular}{|c|l|r|}
\hline No & \multicolumn{1}{|c|}{ Kecamatan } & Hasil \\
\hline 1 & Gerung - Lembar & 19.632 .902 \\
\hline 2 & Gerung - Labuapi & 54.495 .189 \\
\hline 3 & Gerung - Kediri & 28.211 .177 \\
\hline 4 & Gerung - Kuripan & 124.663 .795 \\
\hline
\end{tabular}

Sumber: Data diolah.

Dari hasil diatas dapat dilihat bahwa Kecamatan Gerung memiliki daya tarik yang kuat terhadap daerah belakangnya terutama bagi daerah yang berdekatan. Jarak antar wilayah merupakan salah satu faktor yang mempengaruhi angka indeks gravitasi. Semakin dekat jarak tempuh antara pusat pertumbuhan dengan wilayah hinterland-nya maka semakin tinggi angka indeks gravitasi yang dihasilkan, dengan kata lain tingkat interaksi yang dihasilkan akan semakin kuat.

Daerah yang memiliki interaksi paling kuat dengan pusat pertumbuhan adalah Kecamatan Kuripan dengan nilai indeks sebesar 124.663.795. Keadaan ini bisa dipahami mengingat jarak antar kedua kutub yang cukup dekat (5 km), meskipun penduduk Kuripan relatif sedikit. Karenanya penduduk Kecamatan Kuripan banyak mendapat maanfaat dengan kondisi tersebut. Sebaliknya daerah yang mempunyai tingkat interaksi terendah adalah Kecamatan Lembar, dengan nilai indeks sebesar 19.632.902. Ini tentu bisa dipahami mengingat Kecamatan Lembar adalah kecamatan terjauh jaraknya $(14,5 \mathrm{~km})$ dari pusat pertumbuhan dibandingkan kecamatan lain di sekitarnya. Disamping itu, jumlah penduduk kecamatan ini cukup banyak, yang mencerminkan bahwa meskipun mereka banyak memiliki interaksi dengan pusat pertumbuhan, namun secara proporsional lebih kecil karena faktor jarak tersebut. Dengan hasil perhitungan diatas dapat diketahui bahwa masing-masing daerah memiliki nilai indeks gravitasi yang berbeda, yang mencerminkan kuat-lemahnya hubungan pusat pertumbuhan dengan daerah sekitarnya.

\section{Peranan Pusat Pertumbuhan (Gerung) pada Daerah Pendukung}

Peranan Pusat Pertumbuhan (Gerung) bagi pembangunan ekonomi wilayah, ditunjukkan oleh tingkat pemerataan pendapatan pusat pertumbuhan dan daerah pendukungnya. Kesenjangan pendapatan merupakan salah satu indikator tentang efektif atau tidaknya pusat pertumbuhan dalam memberikan pengaruh spread effect atau backwash effect terhadap daerah pendukung. Salah satu tolok ukur yang bisa digunakan untuk melihat tingkat ketimpangan pendapatan antar daerah, dapat dilihat dari nilai Indeks Willamson. Indeks ini memberikan acuan, apabila hasil indeks yang diperoleh mendekati 0 , maka ketimpangan pendapatan antar daerah semakin kecil, begitu juga sebaliknya, apabila hasil yang diperoleh mendekati 1 maka ketimpangan antar daerah semakin besar. Dengan dasar tersebut, hasil perhitungan Indeks Willamson antar wilayah di Kabupaten Lombok Barat, dapat dilihat pada tabel berikut:

Tabel 3. Hasil Indeks Williamson Kecamatan Pendukung Di Lombok Barat 2017.

\begin{tabular}{|c|l|c|}
\hline No & Kecamatan & Hasil Indeks Williamson \\
\hline 1 & Lembar & 0,164 \\
\hline 2 & Gerung & 0,030 \\
\hline 3 & Labuapi & 0,003 \\
\hline 4 & Kediri & 0,037 \\
\hline 5 & Kuripan & 0,060 \\
& Rata-rata & 0,059 \\
\hline
\end{tabular}

Sumber: Data diolah.

Hasil perhitungan Indeks Williamson untuk empat kecamatan pendukung pusat pertumbuhan di Lombok Barat, semua nilainya mendekati 0. Dan secara rata-rata ketimpangan pendapatan antar daerah tersebut sebesar 0,059 . Hal ini mengindikasikan bahwa pertumbuhan ekonomi di daerah pendukung tersebut di Lombok Barat relatif merata. Kecamatan Labuapi merupakan kecamatan 


\section{Elastisitas - Jurnal Ekonomi Pembangunan \\ Vol. 2 No. 1, Maret 2020}

yang memiliki interaksi terkuat dengan Kecamatan Gerung sebagai pusat pertumbuhan, dengan nilai Indeks sebesar 0,003 , yang merupakan nilai terendah diantara kecamatan lainnya. Nilai yang beda ditunjukkan oleh Kecamatan Lembar yang memiliki tingkat ketimpangan yang relatif lebih tinggi dibandingkan kecamatan lainnya yaitu sebesar 0,169. Hal ini terjadi karena jumlah penduduk Kecamatan Lembar yang relatif lebih sedikit, namun disisi lain memiliki PDRB yang relatif besar. Inilah yang menyebabkan nilai indeksnya menjadi lebih besar. Dengan keadaan ini diharap kedepan, kecamatan lain yang beririsan dengan Lembar bisa terdampak ekonominya lebih meningkat, sehingga mampu menjadi pemicu kenaikan PDRB kecamatan tersebut. Dengan demikian Kecamatan Gerung sebagai pusat pertumbuhan telah mampu memberikan spread effect terhadap kecamatan pendukungnya. Rendahnya tingkat ketimpangan ini juga menggambarkan keberhasilan Lombok Barat secara umum menerapkan kebijakan pembangunan secara regional dengan menempatkan Kecamatan Gerung sebagai pusat pertumbuhan yang telah mampu memberikan efek posistif (spread effect) terhadap Kecamatan/ daerah sekitarnya.

\section{KESIMPULAN}

Berdasarkan hasil pembahasan dapat disimpulkan bahwa secara simultan pusat pertumbuhan dan daerah pendukungnya mengalami pertumbuhan ekonomi yang nyata secara bersama selama pengamatan. Meskipun sedikit fluktuatif (di Lembar dan Kediri), namun secara rata-rata mengarah pada peningkatan. Kecamatan Gerung sebagai wilayah pusat pertumbuhan memiliki daya tarik yang kuat terhadap daerah belakangnya terutama bagi daerah yang berdekatan (Kuripan dan Labuapi). Daerah hinterland yang memiliki interaksi yang kuat dengan pusat pertumbuhan adalah Kecamatan Kuripan. Keadaan ini bisa dipahami mengingat jarak antar kedua kutub yang cukup dekat. Sebaliknya terjadi dengan Kecamatan Lembar dengan tingkat interaksi terendah, karena posisi kecamatan ini yang terjauh dari pusat pertumbuhan (Gerung).

Dari aspek kemerataan pertumbuhan ekonomi antara pusat pertumbuhan dan daerah pendukung menunjukkan pertumbuhan yang relatif berimbang dan tumbuh secara simultan. Kecamatan Labuapi merupakan kecamatan yang memiliki kemerataan perekonomian yang relatif seimbang dengan pusat pertumbuhan, karena memiliki nilai Indeks Williamson paling rendah. Kondisi yang beda ditunjukkan oleh Kecamatan Lembar yang memiliki tingkat ketimpangan yang yang lebih tinggi dibandingkan kecamatan lainnya. Dengan demikian Kecamatan Gerung sebagai pusat pertumbuhan telah mampu memberikan spread effect terhadap kecamatan pendukungnya, karena dapat menjadi pemicu pertumbuhan ekonomi wilayah sekitar/ pendukungnya. Untuk itu perbaikan dan penambahan sarana dan prasarana yang mempermudah saling interaksi tersebut menjadi perhatian utama untuk dibangun, seperti jalan penghubung, transportasi, perijinan dan lainnya.

\section{DAFTAR PUSTAKA}

Adisasmita, Rahardjo. 2005. Dasar-Dasar Ekonomi Wilayah. Graha Ilmu, Yogyakarta.

Adisasmita, Rahardjo. 2008. Pengembangan Wilayah Konsep Dan Teori. Graha Ilmu, Yogyakarta.

Ali, M. J., \& Varshney, D. (2013). Spatial Modelling of Urban Growth and Urban Influence. Environment and Urbanization ASIA, 3(2), 255-275. doi: $10.1177 / 0975425312473225$

Anonim, 2018. Badan Pusat Statistik Kabupaten Lombok Barat 2018. Lombok Barat Dalam Angka 2018, Mataram.

Anonim, 2018. Badan Pusat Statistik Kabupaten Lombok Barat 2018. Kecamaan Sekotong Dalam Angka 2018, Mataram. 


\section{Elastisitas - Jurnal Ekonomi Pembangunan \\ Vol. 2 No. 1, Maret 2020}

Arsyad, Lincolin. 2000. Pengantar Perencanaan dan Pembangunan Ekonomi Daerah, BPFE, Yogyakarta.

Athukorala, P.-c., \& Narayanan, S. (2018). Economic corridors and regional development: The Malaysian experience. World Development 106 (2018) 1-14, 106, 1-14. doi: 10.1016/j.worlddev.2018.01.009

Blair, N., Berry, J., \& McGreal, S. (2007). Regional Spatial Policy for Economic Growth: Lessons from the Deployment of Collaborative Planning in Northern Ireland. Urban Studies, 44(3), 439-455.

Chapple, K., \& Montero, S. (2016). From learning to fragile governance: Regional economic development in rural Peru. Journal of Rural Studies, 44. doi:

10.1016/j.jrurstud.2016.01.009

Duran, H. E. (2019). Asymmetries in regional development: Does TFP or capital accumulation matter for spatial inequalities? The Journal of Economic Asymmetries, 20, e00119. doi: 10.1016/j.jeca.2019.e00119

Gulo, Yarman. 2015. Identifikasi Pusat-Pusat Pertumbuhan Dan Wilayah Pendukungnya Dalam pengembangan Wilayah Kabupaten Nias. Jurnal Widyariset Vol.18, April 2015, Nomor 1.

Hendarto, Mulyo. 2014. Makalah Ekonomi Pengembangan Regional, Jurusan Ilmu Ekonomi dan Studi Pembangunan, Fakultas Ekonomi Universitas Diponegoro, Semarang.
Jin, C., Xu, J., \& Huang, Z. (2019). Spatiotemporal analysis of regional tourism development: A semiparametric Geographically Weighted Regression model approach. Habitat International, 87(1-10). doi: 10.1016/j.habitatint.2019.03.011

Nining, Purnamaningsih. 2009. Pengembangan Wilayah Terintegrasi Secara Ekonomi Dan Spacial di Kediri. Jurnal Fakultas Ekonomi Universitas Kediri .

Nischalke, T., \& Schöllmann, A. (2005). Regional development and regional innovation policy in New Zealand: Issues and tensions in a small remote country. European Planning Studies, 13(4). doi: $10.1080 / 09654310500107217$

Sjafrizal, 2012, Ekonomi Wilayah Dan Perkotaan. Grafindo, Jakarta.

Sugiyono. 2012. Metode Penelitian Pendidikan (Pendekatan Kuantitatif, Kualitatif, dan $R \& D$, Alfabeta, Bandung.

Tarigan. 2005. Ekonomi Regional Teori dan Aplikasi. PT Bumi Aksara, Jakarta.

Sumber online:

1. https://lombokbaratkab.bps.go.id/publication/2018/08/16/ebad430c721719c6d21d 8a1f/kabupaten-lombok-barat-dalamangka-2018.html.

2. https://petatematikindo.wordpress.com.

3. http://lombokbaratkab.go.id/data-danstatistik/\#nimblebox[nimble portfoliodef ault $/ 16 /$

4. https://lombokbaratkab.bps.go.id/

5. https://lombokbaratkab.bps.go.id/subject/12/kependudukan.html\#subjekView$\underline{\mathrm{Tab} 3}$ 